\title{
IJTIHAD PADA MASA KONTEMPORER (Konteks Pemikiran Islam dalam Fiqh Dan Ushul Fiqh)
}

\section{Oleh \\ Turmudi*}

\begin{abstract}
Abstrak:
Islam berkembang dan mencapai kejayaan karena menghormati proses ijtihad ini. Tulisan ini mencoba mengetengahkan bahasan tentang hukum Islam pada masa kontemporer, yang berkenaan dengan pembaharuan dalam konteks pemikiran fiqh dengan pokokpokok bahasan yang terdiri dari pengertian hukum Islam kontemporer, objek kajian hukum Islam kontemporer, fleksibelitas dan keluasan hukum Islam, relevansi fiqh kontemporer dengan doktrin klasik dan pintu ijtihad dibuka kembali. Di antara langkah konkret dalam memecahkan masalah-masalah kontemporer adalah metode lintas madhzab, yakni dengan mempelajari pendapat semua fuqaha dalam semua madzhab fiqh seperti Hanafi, Maliki, Syafi'i, Hanbali, Dhahiri dan lain-lain beserta dalil-dalil dan kaidah-kaidah istinbath masing-masing madzhab dalam membahas suatu persoalan.
\end{abstract}

Kata Kunci: Ijtihad, Fiqh-Ushul Fiqh

\section{Pendahuluan}

Hukum Islam merupakan bagian dari unsur ajaran Islam sebagai pedoman hidup bagi manusia terutama dalam melaksanakan tugas kekhalifahan dimuka bumi. Dalam hal ini Fiqh sebagai hukum Islam cenderung berbicara tentang aspek eksoteris keagamaan yang bersifat legal formal, berhubungan dengan boleh atau tidaknya sesuatu pelaksanaan amaliah atau dengan kata lain sesuatu yang dikaitkan dengan konteks halalharam dalam agama.

Sebagai hukum yang hidup dan berkembang di masyarakat, hukum Islam memiliki ciri khas tersendiri, di antaranya adalah coraknya yang responsif, adaptif dan dinamis yang membuka peluang bagi kehidupan, perubahan dan pembaharuan sesuai dengan semangat zaman. Namun yang

\footnotetext{
* IAI Tribakti Kediri.
} 
selalu menjadi persoalan dalam proses sosialisasi fiqh (hukum Islam) dan sering menjadi ajang perdebatan, yakni dalam hal relevansi maupun aktualisasi hukum itu sendiri, terutama bila dikaitkan dengan keadaan tempat (lokal) maupun zaman (temporal).

Demikian juga halnya dengan munculnya gejala baru dalam pemahaman hukum Islam secara lebih rasional, metodologi modern aktual, cenderung menimbulkan khilafiyah baru di kalangan umat Islam dewasa ini, sebagaimana yang sering kita ikuti lewat berbagai media masa maupun literatur keagamaan lainnya, seperti reaktualisasi ajaran Islam, aktualisasi fiqh muamalah, pembaharuan hukum Islam dan lain-lain.

Tulisan ini mencoba mengetengahkan bahasan tentang hukum Islam pada masa kontemporer, yang berkenaan dengan pembaharuan dalam konteks pemikiran fiqh dengan pokok-pokok bahasan yang terdiri dari pengertian hukum Islam kontemporer, objek kajian hukum Islam kontemporer, fleksibelitas dan keluasan hukum Islam, relevansi fiqh kontemporer dengan doktrin klasik dan pintu ijtihad dibuka kembali.

\section{Pembahasan}

\section{Pengertian Hukum Islam pada Masa Kontemporer}

Yang dimaksud dengan hukum Islam pada masa kontemporer adalah hukum Islam pada masa kini atau dewasa ini. ${ }^{1}$ Sedang yang dimaksud dengan hukum Islam dalam konteks ini adalah fiqh. Jadi hukum Islam kontemporer adalah perkembangan pemikiran fiqh Islam dewasa ini.

Adapun penyebutan kontemporer pada fiqh maksudnya adalah pola pemahaman fiqh abad XIX dan seterusnya (hingga sekarang) lawan dari klasik (fiqh klasik) yaitu pola pemahaman fiqh abad VII-XII. ${ }^{2}$

Namun dari pengamatan yang ada, sering muncul istilah hukum Islam kontemporer adalah padanan dari masail fiqhiah, yaitu kajian fiqh atas isu-isu kontemporer. Hal ini, misalnya, dapat dilihat dari berbagai buku yang secara

${ }^{1}$ Kontemporer berarti: [1] sewaktu, semasa, pada waktu atau masa yang sama, [2] pada masa kini, dewasa ini. Selanjutnya lihat Poerwadarminto, Kamus Umum Bahasa Indonesia, Jakarta, Balai Pustaka, 1986.

${ }^{2}$ Fase Fiqh Klasik dan Fiqh Kontemporer ini didasarkan pada pembagian zaman tentang ciri pemikiran Islam oleh Harun Nasution yaitu zaman klasik (rasional) abad VIIXII, zaman pertengahan (tradisional) abad XIII-XVIII dan zaman modern (kontemporer) abad XIX dan seterusnya, sebagaimana yang dikutip oleh Muhammad Azhar, Fiqh Kontemporer dalam Pandangan Neomodernisme Islam, Pustaka Pelajar, Yogyakarta,1996, hlm. 18 . 
khusus diberi judul masail fiqhiyah atau problematika hukum Islam kontemporer. ${ }^{3}$

Dari tema-tema yang diangkat dapat dipahami bahwa yang dimaksud dengan hukum Islam kontemporer adalah perspektif hukum Islam terhadap masalah-masalah kekinian.

Banyak sekali kasus baru atau problematika kekinian yang belum pernah muncul sebelumnya dipaparkan dan diulas. Karena itu, sangat logis jika pengertian hukum Islam kontemporer seperti itu dikesankan bersifat responsif. Artinya, fiqh dewasa ini mecoba merespons persoalan-persoalan baru yang meminta penjelasan dari aspek status hukum (halal-haram)nya.

Di samping itu, hukum Islam kontemporer juga mencoba untuk melihat perubahan-perubahan signifikan hukum Islam dari masa ke masa. Perubahan-perubahan signifikan itu muncul sebagai akibat, antara lain yang paling menonjol adalah perkembangan zaman yang selalu meminta etika dan paradigma baru.

\section{Objek Kajian Hukum Islam Kontemporer}

Dengan melihat muatan pembahasan dalam buku-buku masail fiqhiyah dan fatwa-fatwa kontemporer, maka kajian hukum Islam kontemporer dapat dikategorikan ke dalam beberapa aspek:

a. Aspek hukum keluarga. Yang dimaksud hukum keluarga di sini adalah seluruh yang terkait dengan al-ahwal al-syakhshiyah antara lain meliputi: pembagian harta waris, aqad nikah via telepon, perwakafan, nikah hamil, KB dan lain-lain.

b. Aspek ekonomi. Ini banyak terkait dengan penafsiran terhadap persoalan tiba dan pengelolaan modern zakat. Karena ini hukum Islam kontemporer selalu menyorot masalah sistem bunga bank, zakat mal dan perpajakan, kredit dan arisan, zakat profesi, zakat produktif dan konsumtif, asuransi dan lain-lain.

c. Aspek pidana. Biasanya pembahasan tentang aspek pidana sarat dengan isu-isu HAM dan humanisme agama. Hukum Islam kontemporer mencoba memberikan tafsiran baru terhadap masalah

${ }^{3}$ Di antara buku-buku yang mengulas berbagai persoalan kontemporer dalam perspektif hukum Islam: "Masail Fiqhiyah" karya Masyfuk Zuhdi, "Masail Fiqhiyah" karya HM. Ali Hasan, "Masail Fiqhiyah" karya M. Mahyudin, "Problematika Hukum Islam Kontemporer", editor Huzaemah T. Yanggo, "Kajian Islam tentang Berbagai Masalah Kontemporer", oleh IAIN "Syahid", "Yang Hangat dan Kontroversial dalam Fiqh", karya Ja'far Subhani. 
qishash, potong tangan, hukum Islam dalam sistem hukum nasional dan seterusnya.

d. Aspek kewanitaan. Gaung dari mereka yang menyuarakan gender cukup mendominasi pembahasan hukum Islam kontemporer, di samping peran serta kalangan wanita dalam aktivitas-aktivitas yang dahulu dianggap sebagai "wilayah laki". Terlihat, hukum Islam kontemporer banyak menyorot masalah busana muslimah, wanita karir, kepemimpinan wanita dan lainnya.

e. Aspek medis. Perkembangan dalam ilmu kedokteran yang sangat pesat mendapat perhatian besar dalam kajian-kajian hukum Islam kontemporer, sejumlah isu medis menghiasi pembahasan masail fiqhiyah, antara lain : pencangkokan organ tubuh, donor darah, bedah mayat, alat-alat kontrasepsi, euthanasia, infertilitas dan fertilitas, operasi ganti kelamin, pemilihan jenis kelamin janin, cloning, bayi tabung atau inseminasi buatan, bank air susu, bank darah, bank sperma, inseminasi sperma manusia dengan hewan dan sebagainya.

f. Aspek teknologi. Perkembangan teknologi yang menciptakan berbagai kemudahan juga tidak luput dari sorotan hukum Islam kontemporer, antara lain menyembelih binatang secara mekanis, seruan adzan melalui kaset, makmum kepada radio atau televisi, memberi salam dengan bel, penggunaan hisab dan sebagainya.

g. Aspek politik. Beberapa kasus menarik adalah perdebatan tentang istilah negara Islam, proses pemilihan pemimpin, loyalitas kepada penguasa dan seterusnya.

h. Aspek ibadah. Tidak kalah menarik adalah wacana yang berkembang di sekitar soal ibadah, seperti; tabungan haji, tayamum dengan selain tanah (debu), ibadah kurban dengan uang, menahan haid demi ibadah haji dan lain-lain. ${ }^{4}$

Dari berbagai persoalan baru muncul, semakin menguatkan hipotesis tentang keterkaitan dan ketertautan fiqh dengan konteks-konteks kehidupan yang nyata, dimana fiqh itu pada dasarnya bukanlah suatu ilmu teoritis (ulum nadhariyah) tetapi bidang garapannya adalah ketentuan-ketentuan yang berlaku positif (ahkam amaliyah). ${ }^{5}$

\footnotetext{
${ }^{4}$ Muhammad Azhar, Fiqh Kontemporer dalam Pandangan Neomodernisme Islam, hlm. 22-24.

${ }^{5}$ Lihat Ali Yafie, dalam kata pengantar buku Mun'in A. Sirry, Sejarah Fiqh Islam, Sebuah Pengantar, Risalah Gusti, Surabaya, 1996, Cet. II hlm. viii.
} 
Bahkan jika kita ingin melihat benturan-benturan Islam dengan kenyataan-kenyataan sosial, maka kita harus mengkaji fiqh, bukan ilmu kalam atau taswuf. Sejak awal, hukum Islam telah dianggap sebagai pengetahuan yang exellence, suatu posisi yang belum pernah dicapai teologi. Itulah sebabnya para pengamat Barat menilai bahwa "adalah mustahil memahami Islam tanpa memahami hukum Islam". ${ }^{6}$

\section{Fleksibelitas dan Keluasan Hukum Islam}

Ajaran Islam bersifat serba-segi, meliputi segala keperluan hidup dan kehidupan manusia, lahir batin, dunia dan akhirat. Hukum Islam mengandung sifat-sifat universal yang serba mencakup semua aturan hidup yang terdapat dalam al-Qur'an dan Sunnah. Tempat dan waktu senantiasa dapat menyesuaikan diri dengan patokan-patokan umum al-Qur'an, bukan sebaliknya. Sedangkan usaha menyesuaikan diri itulah yang menjadi daerah bergerak bagi para mujtahid hukum, sehingga penerapan hukum Islam dapat berjalan dengan sewajarnya di tempat masing-masing dengan waktu dan keadaannya. ${ }^{7}$

Bukti historis menunjukkan, selama kira-kira 13 abad, ${ }^{8}$ syariat Islam telah menjadi pedoman utama di seluruh dunia Islam yang masyarakatnya beragam, sistem pemerintahannya bermacam-macam dan budaya peradabannya beraneka. Selama itu Undang-Undang (tasyri), pengambilan keputusan (qadla) dan penetapan hukum kontemporer (fatwa). Syari'at tidak pernah buntu untuk persoalan baru, selalu menyediakan jalan keluar bagi pemecahannya. ${ }^{9}$ Ruang gerak dinamika hukum Islam dapat dinilai dalam tiga hal. Pertama, adanya nash-nash yang turun secara global yang pelaksanaannya memerlukan penafsiran dan penjabaran lebih lanjut. Kedua, kita dapat memberikan hukum terhadap suatu peristiwa baru yang melihat nash hukum pada peristiwa lain yang punya 'illat sama. Dalam bahasa

${ }^{6}$ Joseph Schacht, An Introduction to Islamic Law, Oxford Press, London, 1971.
${ }^{7}$ Anwar Harjono, Hukum Islam Keluasan dan Keadilannya, Bulan Bintang, Jakarta, hlm. 113 .

${ }^{8}$ Semenjak Nabi Muhammad saw. Khalifah Al-Rasyidin, Bani Umayyah, Bani Abbasiyyah dan berakhir pada masa Turki Usmani yang merupakan simbol terakhir kekuasaan politik dan kemajuan umat Islam memasuki abad modern. Umara dan ulama Turki menentang pembukaan pintu ijtihad dan menetapkan madzhab Hanafi sebagai satusatunya al-Hawali, al-Ilmaniah Nasyatuha wa Thathawuruha wa Mekkah, Beirut, t.t., hlm. 21.

${ }^{9}$ Yusuf Qardhawi, Keluwesan dan Keluasan Syari'at Islam dalam menghadapi Perubahan Zaman, Pustaka Firdaus, 1996, hlm. 3. 
fuqaha, legitimasi hukum, seperti ini disebut qiyas atau pengambilan hukum secara analogis. Ketiga, adanya kaidah-kaidah umum dan prinsip-prinsip mashlahah sesuai dengan maqashid syariah. ${ }^{10}$ Dengan meletakkan tiga faktor dinamika hukum Islam ini, kita dapat memahami pernyataan Imam al-Syafi'i bahwa "tidak ada sesuatu apapun yang dihadapi oleh manusia, kecuali ia akan menemukan ketentuan-ketentuan hukumnya dalam al-Qur'an."11

\section{Relevansi Fiqh Kontemporer Dengan Doktrin Klasik}

Menurut Harun Nasution, ${ }^{12}$ metode berfikir ulama klasik terikat langsung dengan al-Qur'an dan hadits, sehingga banyak melahirkan ijtihad yang kualitatif, hal ini banyak dicontohkan oleh para sahabat Nabi, terutama Umar bin Khattab. Metode berfikir itu pulalah yang ditiru oleh Imam-Imam madzhab fiqh seperti Malik ibn Anas, Abu Hanifah, Syafi'i dan ibn Hambal. Juga oleh para mutakallimin seperti Washil bin Atha'. Abu al-Huzail, alJubbai, al-Asy'ari, al-Maturidi dan al-Ghazali. Juga oleh para kaum sufi, seperti Zunnum al-Mishri, Abu Yazid al-Bustami, al-Hallaj dan al-Ghazali. Para filosof Islam seperti al-Kindi, al-Farabi, Ibnu Sina dan al-Ghazali juga memahami metode berfikir yang sama.

Sebenarnya bila umat Islam ingin maju dan punya kemampuan untuk mengantisipasi perkembangan zaman modern, pola pemikiran para sahabat dan ulama klasik sudah selayaknya untuk dikembangkan lagi. Di sinilah letak relevansinya antara fiqh kontemporer dengan fiqh klasik nantinya, yakni dalam pola penalaran fiqhiyahnya, walaupun akan menghasilkan produk fiqh yang karena perbedaan situasi dan kondisi yang ada. Namun walaupun demikian, bukan berarti harus menafikan khazanah pemikiran Islam abad klasik atau abad pertengahan, tapi yang jelas pemikiran kontemporer tidak mesti terikat secara kaku dengan hasil kajian ulama pertengahan maupun klasik, bila ternyata tidak relevan dengan persoalan yang ada, tetapi yang masih relevan tetap dapat dijadikan pegangan. Ini yang diistilahkan dengan: memelihara yang lama yang masih baik (relevan) dan mengambil pendapat yang baru yang lebih baik (lebih relevan).

\footnotetext{
${ }^{10}$ Mun'im A. Sirry, Sejarah Fikih, hlm. 7.

${ }^{11}$ Imam Syafi'i, Al-Risalah, ed. Ahmad M. Syakir, Dar al-Kutub Ilmiyah, Beirut, t.t., hlm. 21 .

${ }^{12}$ Sebagaimana dikutip oleh Muhammad Azhar, Fiqh Kontemporer, hlm. 19 dari makalah Seminar Nasional Ukhuwah Islamiyah, IAIN Sumut, 1990.
} 
Hal tersebut di atas sangat sesuai dengan firman Allah swt. dalam surat Az-Zumar ayat 18 yang artinya mereka yang mendengarkan perkataan (opini), lalu mengikuti apa yang paling baik diantaranya, mereka itulah orang-orang yang diberi Allah petunjuk dan mereka itulah orang-orang yang mempunyai akal. Sebenarnya ulama klasik sendiri (dalam hal ini Imam yang empat; Abu Hanifah, Malik, Syafi'i dan Ahmad bin Hambal) tidak menginginkan adanya madzhab-madzhab dalam Islam, terbukti dari ungkapan-ungkapan mereka :

1. Kata Abu Hanifah

"Jika perkataanku menyalahi kitab Allah dan Hadits Rasulnya, maka tinggalkan perkataanku".

2. Kata Imam Malik

"Sebenarnya aku ini seorang manusia; mungkin salah dan mungkin benar. Maka selidikilah olehmu semua pendapatku. Tiap-tiap yang sesuai dengan kitab dan sunnah, ambillah dan yang tidak sesuai dengan kitab dan sunnah, tinggalkanlah".

3. Kata Imam Syafi'i

"Apabila telah shah hadits, itulah madzhab'.

4. Kata Imam Ahmad bin Hambal

"Jangan engkau bertaqlid kepadaku; jangan engkau bertaqlid kepada Malik dan jangan enkau bertaqlid kepada Auza'i. Tetapi ambillah olehmu dari tempat mereka mengambilnya". ${ }^{13}$

Demikianlah keempat imam itu berpesan dan mengajak umat supaya jangan menganggap pendapat mereka itu sebagai pendapat terakhir dan tertinggi yang sudah tak dapat diganggu gugat lagi.

Mereka tegaskan, bahwa sumber-sumber pengambilan hukum mereka adalah al-Qur'an dan al-Hadits, karena itu dianjurkan supaya umat sesudah mereka juga mengambil hukum dari sumber al-Qur'an dan al-Hadits itu pula.

Hendaknya para pemikir Islam kontemporer dapat diwarisi sikap inilah para sahabat Nabi maupun ulama klasik terutama dalam memahami fiqh (hukum) Islam.

${ }^{13}$ Anwar Harjono, Hukum Islam, hlm. 104-105, lihat juga dan bandingkan dengan Muhammad Azhar, Fiqh Kontemporer, hlm. 20-22. 


\section{Pintu Ijtihad Dibuka Kembali}

Perubahan dan perkembangan dunia yang begitu menglobal, apakah syari'at Islam dapat merespons? Apakah hukum-hukum Islam itu cocok untuk diterapkan pada zaman sekarang? Jawabnya, syariat Islam adalah kekal abadi, mampu menghadapi dan merespons problematika kontemporer dan sanggup untuk mengatasinya. Ia mampu mengarahkan dan membimbing kehidupan ini di atas jalan hidayah Allah. Problem kontemporer tersebut dapat direspons dan diatasi oleh syariat Islam, akan tetapi dengan beberapa syarat yang harus ditempuhnya. Di antaranya, membuka pintu ijtihad bagi mereka yang mampu dan kembali mengikuti jejak salafus shaleh serta melepaskan diri dari fanatisme madzhab dalam hal yang berkaitan dengan tasyri' untuk masyarakat seluruhnya.

Pintu ijtihad telah Nabi saw. tidak ada ada seorangpun yang berhak untuk menutupnya. al-Qur'an maupun al-Hadits tidak mengharuskan kita untuk terikat satu madzhab fiqh tertentu. Bahkan, pernyataan-pernyataan para imam madzhab banyak yang melarang bertaqlid dalam hal-hal yang diijtihadi mereka. ${ }^{14}$

Perkembangan ilmu pengetahuan dan teknologi pada abad modern ini, menuntut para pemikir Islam untuk mengadakan upaya rekonstruksi terhadap khazanah pengetahuan Islam secara inovatif. Termasuk yang cukup urgen adalah upaya para pemikir tersebut untuk secara terus menerus melakukan ijtihad secara benar dan dapat dipertanggungjawabkan terutama tentang hal-hal yang berkaitan dengan pemahaman para ulama pada masa lalu. Kajian tentang ijtihad akan selalu aktual mangingat kedudukan dan fungsi ijtihad dalam yurisprudensi Islam tidak bisa dipisahkan dengan produk-produk fiqh, baik sebagai purifikasi maupun reaktualisasi. ${ }^{15}$

Pentingnya ijtihad juga dikatakan oleh al-Zuhaili, bahwa ijtihad adalah nafasnya hukum Islam. ${ }^{16}$ Oleh sebab itu kalau ijtihad ini terhenti, maka hukum Islam pun akan terhenti perkembangannya dan akan terus tertinggal oleh dinamika kemajuan masyarakat.

\footnotetext{
${ }^{14}$ Yusuf Qardhawi, Membumikan Syariat Islam, Dunia Ilmu Offset, Surabaya, 1990, cet. I, hlm. 286.

${ }^{15}$ Yusuf Qardhawi, al-Ijtihad al-Mu'ashir baina al-Intibaath wa al-Infiraat, Darul Tauzij wa al-Nasyr al-Islamiyah, 1994, hlm. 5. 1978, hlm. 480.

${ }^{16}$ Wahbah al-Zuhaili, al-Wasith fiUshul al-Figh al-Islami, Dar al-Kitab, Damascus,
} 
Dalam sejarah hukum Islam, kegiatan ijtihad pernah mengalami kemandegan karena munculnya anggapan bahwa bahwa pintu ijtihad telah tertutup, sehingga pada masa ini umat Islam mengalami era taqlid yang begitu panjang. Yang menjadi pertanyaan adalah apakah benar bahwa ijtihad itu telah tertutup? Pada masa ini fiqh aktual mengalami masa surut dan puncak kemundurannya terjadi pada awal abad ke-19 di kerajaan Turki Usmani.

Akan tetapi dengan datangnya masa modern (menjelang abad ke-19), para modernis muslim lebih menyerukan ijtihad dengan urgensi yang lebih besar sejak pembenturan antara masyarakat muslim dengan kekuatankekuatan baru dalam semua bentuknya. Tokoh-tokoh yang paling gigih dan berjasa dalam membangkitkan kembali gerakan ijtihad ini, antara lain: Jamal al-Din al-Afghany (1839-1897 M), M. Abduh (1849-1905 M), Rasyid Ridha (1865-1935 M), al-Thathawy (1801-1873 M) dan lain-lain di Mesir. Sedangkan di India adalah Syah Waliyullah (1703-1762 M), Sayyid Ahmad Khan (1817-1898 M), Sayyid Amir Ali (1849-1928 M) dan lain-lain. ${ }^{17}$

Adapun konsep ijtihad pada masa kontemporer di sini dapat dikemukakan tentang ijtihad menurut Yusuf Qardhawi yaitu ijtihad Intiqa'i dan ijtihad Insya' ${ }^{18}{ }^{18}$ Yang dimaksud dengan ijtihad intiqa'i ialah memilih satu pendapat dari beberapa pendapat terkuat yang terdapat pada warisan fiqh Islam, yang penuh dengan fatwa dan keputusan hukum. Cara adalah dengan mengadakan tudi komparatif terhadap pendapat itu dan meneliti kembali dalil-dalil nash atau dalil-dalil ijtihad yang dijadikan sandaran pendapat tersebut, sehingga akhirnya kita dapat memilih pendapat yang terkuat dalilnya dan alasannya pun sesuai dengan kaidah tarjih, di antaranya; hendaknya pendapat itu mencerminkan kelemah-lembutan dan kasih sayang kepada manusia. Hendaknya pendapat itu lebih mendekati kemudahan yang ditetapkan oleh hukum Islam; hendaknya pendapat itu lebih memprioritaskan untuk merealisasikan maksud-maksud syara', kemashlahatan manusia dan menolak marabahaya dari mereka.

Yang dimaksud dengan ijtihad Insya'i adalah pengambilan konklusi hukum baru dari suatu persoalan, yang persoalan itu belum pernah dikemukakan oleh ulama-ulama terdahulu. Baik itu persoalan lama atau baru. Dengan kata lain, bahwa ijtihad insya'i adalah meliputi sebagian persoalan

\footnotetext{
${ }^{17}$ Huzaemah Tahido Yanggo, Pengantar Perbandingan Madzhab, Logos, Jakarta, 1997, hlm. 44.

${ }^{18}$ Yusuf Qardhawi, al-Ijtihad ..., hlm. 29-47.
} 
lama, yaitu dengan cara seorang mujtahid kontemporer untuk memiliki pendapat baru dalam masalah itu yang belum didapati dari pendapat ulamaulama salaf. Dan yang demikian itu sah-sah saja, berkat karunia Allah.

Pelaku ijtihad dapat dibedakan ijtihad fardi dan ijtihad jama'i. Ijtihad fardi adalah ijtihad yang dilakukan oleh perorangan atau beberapa orang tidak mencakup seluruh mujtahid atau mayoritasnya dalam menentukan hukum suatu masalah, sah dan tidak ada keterangan bahwa semua mujtahid menyetujuinya. Ijtihad fardi ini seperti diriwayatkan dalam hadits tentang ijtihad yang dilakukan oleh Muaz. Ijtihad ini merupakan jembatan atau sarana menuju tercapainya atau terbentuknya ijtihad jama'i dengan berbagai dukungan yang diberikan dalam bentuk kajian yang mendalam atau hasil penelitian yang murni. Ijtihad jama'i adalah kesepakatan para mujtahid terhadap suatu hukum syara', yang belum terjadi pada masa Rasul saw. Kesepakatan dari ijtihad jama'i dalam kitab-kitab ushul fiqh disebut dengan ijma'. 19

Walaupun banyak ahli hukum Islam menolak kemungkinan adanya ijma', namun ijma' sebagai suatu metode penetapan hukum, senantiasa menarik perhatian para ahli fikir. Muhammad Iqbal misalnya, telah memberikan interpretasi ijma' dalam zaman modern ini sebagai dapat dicapai dengan memindahkan ijtihad perorangan yang mewakili aliran-aliran itu dalam suatu majlis perwakilan umat Islam. ${ }^{20}$

\section{Kesimpulan}

Dari uraian di atas dapatlah ditarik beberapa kesimpulan bahwa semakin banyaknya permasalahan yang timbul di abad modern ini merupakan tantangan tersendiri bagi hukum Islam. Dan tantangan ini membuat banyak pemikir muslim yang peduli akan masa depan hukum Islam mengadakan langkah inovatif terhadap karya-karya ulama terdahulu, terutama yang berhubungan dengan masalah hukum. Langkah inovatif inilah yang disebut sebagai ijtihad. Karena dengan adanya ijtihad ini akan menunjukkan bahwa hukum Islam itu luas dan luwes.

t.t., hlm. 106.

${ }^{19}$ Thayib Khudri al-Sayyid, al-Ijtihad fi ma la Nashsha fih, Dar al-Ma'arif, Kairo,

${ }^{20}$ Anwar Harjono, Hukum Islam, hlm. 105.

Al-Hawali, Safar ibn Abd al-Rahman, al-Ilmaniah Nasyatuha wa Thathawwuruha wa Atsaruha fi al-Hayah al-Islamiyah al-Mu'ashirah, (Makkah : Dar Makkah, t.t.). 
Di antara langkah konkret dalam memecahkan masalah-masalah kontemporer adalah metode lintas madhzab (perbandingan madzhab), yakni dengan mempelajari pendapat semua fuqaha dalam semua madzhab fiqh seperti Hanafi, Maliki, Syafi'i, Hanbali, Dhahiri dan lain-lain beserta dalildalil dan kaidah-kaidah istinbath masing-masing madzhab dalam membahas suatu persoalan. Kemudian dibanding antara satu pendapat dengan pendapat lain, untuk kemudian dipilih satu pendapat yang lebih benar, karena didukung oleh dalil terkuat atau dengan mengetengahkan pendapat baru yang dapat digali dari al-Qur'an dan Sunnah melalui metode kajian ushuli, qaidah istinbath, maqashid syariah dan ilmu-ilmu bantu lainnya secara obyektif dan terlepas dari pengaruh pendapat dan pembelaan terhadap madhzab tertentu, serta terjauh dari segala unsur subyektifitas pribadi, golongan dan lain-lain. Selanjutnya pendapat itu dibandingkan dengan hukum positif dengan tidak perlu memaksakan pendapat dari pendirian pembahasnya sendiri. Wallahu a'lam bi al-Shawab. 


\section{DAFTAR PUSTAKA}

Al-Qardhawi, Yusuf, al-Ijtihad al-Mu'ashir baina al-Intibaath wa alInfiraat, (Surabaya : Risalah Gusti, 1995).

Al-Qardhawi, Yusuf, Keluwesan dan Keluasan Syari'at Islam dalam menghadapi Perubahan Zaman, (Jakarta : Pustaka Firdaus, 1996).

Al-Qardhawi, Yusuf, Membumikan Syariat Islam, (Surabaya : Dunia Ilmu Offset 1990).

Al-Sayyid, Thayib Khudri, al-Ijtihad fi ma la Nashsha fih, (Kairo : Dar alMa'arif, t.t.)

Al-Zuhaili, Wahbah, al-Wasith fiUshul al-Fiqh al-Islami, (Damascus : Dar al-Kitab, 1978).

Azhar, Muhammad, Fiqh Kontemporer dalam Pandangan Neomodernisme Islam, (Yogyakarta : Pustaka Pelajar, 1996)

Harjono, Anwar, Hukum Islam Keluasan dan Keadilannya, (Jakarta : Bulan Bintang, t.t.)

Hasan, M. Ali, Masail Fiqhiyah al-Haditsah, (Jakarta : Rajawali Press, 1996)

Poerwadarminto, Kamus Umum Bahasa Indonesia, (Jakarta :Balai Pustaka, 1986).

Schacht, Joseph, An Introduction to Islamic Law, (London : Oxford Press, 1971).

Sirry, Mun'in A., Sejarah Fiqh Islam, (Surabaya : Risalah Gusti 1996).

Syafi'i, Imam, Al-Risalah, ed. Ahmad M. Syakir, (Beirut : Dar al-Kutub Ilmiyah, t.t.)

Yanggo, Huzaemah Tahido, Pengantar Perbandingan Madzhab, (Jakarta : Logos, 1997). 